\title{
ANALISIS KEMAMPUAN PEMAHAMAN MATEMATIK SISWA SMP KELAS VII PADA MATERI BANGUN DATAR
}

\author{
Asep Tantowi ${ }^{1}$, Euis Eti Rohaeti ${ }^{2}$, M. Afrilianto ${ }^{3}$ \\ 1.2.3 IKIP Siliwangi, JL. Terusan Jendral Suirman Cimahi 40526 \\ ${ }^{1}$ aseptantowi@gmail.com, ${ }^{2}$ e2rht@ikipsiliwangi.ac.id, ${ }^{3}$ muhammadafrilianto@ikipsiliwangi.ac.id
}

\begin{abstract}
This study aims to determine the level of ability of mathematical understanding of junior high school students VII in Karawang on the matter of building flat. The type of research used is a qualitative descriptive research. Sempel in this research is students of SMP Negeri 1 Batujaya. The data collected in the form of written test results as much as 5 items that refer to the ability of students' mathematical understanding. Most students can not understand what the problem wants. Based on the results of research students average percentage of results from the test description is only reached $58 \%$. Judging from the test results can be said that students' mathematical understanding ability is still low.
\end{abstract}

Keywords: Mathematical Understanding, Build Flat

\begin{abstract}
Abstrak
Penelitian ini bertujuan untuk mengetahui tingkat kemampuan pemahaman matematis siswa SMP kelas VII yang ada di karawang pada materi bangun datar. Jenis penelitian yang digunakan yaitu berupa penelitian deskriptif kualitatif. Sempel dalam penelitian ini yaitu siswa SMP Negeri 1 Batujaya. Data yang dikumpulkan berupa hasil tes tertulis sebanyak 5 butir soal yang mengacu kepada kemampuan pemahaman matematis siswa. Sebagian besar siswa tidak dapat memahami yang di inginkan oleh soal. Berdasarkan hasil penelitian siswa rata-rata prosentase hasil dari tes uraian yaitu hanya mencapai 58\%. Dilihat dari dari hasil tes tersebut dapat dikatakan kemampuan pemahaman matematis siswa masih rendah.
\end{abstract}

Kata Kunci: Pemahaman Matematis, Bangun Datar

How to cite: Tantowi, A., Rohaeti, E. E., \& Afrilianto, M. (2018). Analisis Kemampuan Pemahaman Matematik Siswa SMP Kelas VII pada Materi Bangun Datar. JPMI - Jurnal Pembelajaran Matematika Inovatif, 1 (4), 687-694.

\section{PENDAHULUAN}

Matematik merupakan salah satu ilmu dasar yang harus dikuasai setiap insan, terutama oleh para pelajar di sekolah-sekolah yang ada. Dengan perkembangan teknologi yang begitu pesat dewasa ini, para pendidik diharapkan dapat mengembangkan metode pembelajaran sesuai dengan kompetensi dasar matematika yang disusun sebagai landasan pembelajaran untuk mengembangkan kemampuan tersebut. Senada dengan yang di utarakan Afrilianto (2012) matematika merupakan salah satu disiplin ilmu dalam dunia pendidikan yang memegang peranan penting dalam perkembangan sains dan teknologi. Warih, Dwi, Parta, \& Rahardjo, (2016) menyatakan bahwa masalah utama yang sering dihadapi pada pelajaran matematika adalah rendahnya kemampuan pemahaman konsep siswa.

Kemampuan pemahaman matematik adalah salah satu tujuan penting dalam pembelajaran, memberikan pengertian bahwa materi-materi yang diajarkan kepada siswa bukan hanya sebagai hafalan, namun lebih dari itu dengan pemahaman siswa dapat lebih mengerti akan konsep materi pelajaran itu sendiri. Pemahaman matematik juga merupakan salah satu tujuan dari 
setiap materi yang disampaikan oleh guru, sebab guru merupakan pembimbing siswa untuk mencapai konsep yang diharapkan. Melihat dari pentingnya memiliki kemampuan pemahaman matematika, pendidik harus merancang pembelajaran yang lebih inovatif agar siswa mencapai hasil belajar yang lebih baik. Wiharno (Hendriana, Rohaeti, \& Sumarmo, 2017) mengatakan bahwa kemampuan pemahaman matematis merupakan suatu kekuatan yang harus diperehatikan selama proses pembelajaran matematika, terutama untuk memperoleh pengetahuan matematika yang bermakna. Pakar lain, Skemp (Hendriana et al., 2017) menyatakan bahwa terdapat dua jenis kemampuan pemahaman yaitu: a) pemahaman instrumental yang artinya hafal sesuatu secara terpisah atau dapat menerapkan sesuatu pada perhitungan rutin/sederhana, mengerjakan sesuatu secara algoritmik. Pada pemahaman ini siswa hanya menghafal rumus dan mengikuti urutan pengerjaan dan algoritma saja; dan b) pemahaman relasional yang berarti dapat melakukan perhitungan secara bermakna pada permasalahan-permasalahan yang lebih luas, termuat skema atau struktur yang dapat digunakan pada penyelesaian yang memuat masalah yang lebih luas, dapat mengaitkan suatu konsep/prinsip lainnya dan sifat pemakaiannya lebih bermakna.

Permasalahan pada kemampuan pemahaman metematis banyak ditemukan sekolah menengah pertama. siswa kesulitan dalam mengungkapkan cara lain untuk menjawab soal. Siswa cenderung hafalan untuk menyelesaikan soal. Hendriana, Rohaeti, \& Sumarmo, (2017) merinci indikator pemahaman matematis ke dalam kegiatan sebagai berikut. a) mendefinisikan konsep secara verbal dan tulisan; b) mendefinisikan dan membuat contoh dan bukan contoh; c) menggunakan model, diagram dan simbol-simbol untuk memperesentasikan suatu konsep; d) mengubah suatu bentuk representasi ke bentuk representasi lainnya; e) mengenal berbagai makna dan interpretasi konsep; f) mengidentifikasi sifat-sifat suatu konsep dan mengenal syarat yang menentukan suatu konsep; g) membandingkan dan membedakan konsep-konsep. Dari beberapa pendapat diatas dapat disimpulkan bahwa kemampuan pemahaman matematis adalah suatu kemampuan menyerap suatu informasi atau materi, rumus dan konsep matematika serta menerapkanna dalam suatu kasus yang dihadapi sehingga siswa dapat menyelesaikan kasus tersebut.

Fakta yang ditemui oleh peneliti yaitu ketika melakukan wawancara baik dengan guru mata pelajaran ataupun dengan siswa ternyata ketika siswa diberi materi oleh gurunya, mereka tidak begitu mengerti dengan apa yang disampaikan, selain itu melihat dari cara siswa menjawab soal yang diberikan oleh guru siswa menjawab pertanyaan tersebut tidak sesuai dengan apa yang diinginkan pertanyaan tersebut. Hal ini disebabkan karena lemahnya siswa dalam memahami materi dan soal tersebut.

Oleh karena itu, peneliti melakukan observasi bertujuan untuk mengetahui sejauh mana kemampuan pemahaman matematis siswa serta dengan siswa dapat memahami suatu materi atau kasus siswa dapat menyelesaikan kasus tersebut dengan lebih terarah. Dengan diadakan penelitian ini siswa dapat lebih memahami materi dan kasus serta konsep matematika dan juga pendidik dapat mengembangkan pembelajaran agar kedepan siswa dapat mudah memahami materi yang disampaikan oleh pendidik.

Pendahuluan menyajikan tujuan penelitian yang dilaporkan dan hubungannya dengan pekerjaan sebelumnya di lapangan. Seharusnya tidak ada ulasan ekstensif tentang literatur. Gunakan hanya referensi yang diperlukan untuk memberikan latar belakang yang paling menonjol agar pembaca dapat memahami dan mengevaluasi tujuan dan hasil penelitian ini tanpa mengacu pada publikasi sebelumnya mengenai topik ini. 


\section{METODE}

Penelitian ini merupakan penelitian dskriptif dengan menggunakan pendekatan kualitatif. Ushalihah (2017) mengatakan bahwa penelitian deskriptif bertujuan untuk menggambarkan secara tepat sifat-sifat suatu individu, keadaan gejala atau kelompok tertentu. Sementara itu, Warih, Dwi, Parta, \& Rahardjo (2016) mengungkapkan metode penelitian kualitatif sebagai prosedur penelitian yang menghasilkan data deskripstif berupa kata-kata tertulis atau lisan dari orang-orang dan perilaku yang dapat diamati.

Penelitian ini ditulis untuk menganalisis dan mendeskripsikan kemampuan pemahaman matematis siswa kelas VII dalam materi Bangun datar yang berpedoman pada terpenuhi atau tidaknya indikator-indikator pemahaman matematis. Tricahyo (2016) Subjek penelitian ini adalah 5 siswa kelas VII yang diambil secara proposive sampling yaitu teknik pengambilan sampel sumber data dengan pertimbangan tertentu. Teknik pengambilan data pada penelitian ini dilakukan dengan menggunakan tes dalam bentuk uraian yang dibuat oleh peneliti. Ruseffendi (2005) menyatakan tes uraian sering juga disebut tes tipe subjektif, sebab skor pekerjaan seseorang dipengaruhi oleh penilai: latar belakang penile, kemampuan memahami dari penilai, kondisi penilai, dan sebagainya. Prosedur dalam penelitian ini terdiri dari 3 tahap yaitu: 1) tahap persiapan, dalam tahap persiapan peneliti melakukan beberapa hal diantaranya melakukan pra riset kepada sampel (siswa), menyiapkan instrumen soal kemampuan pemahaman. 2) tahap pelaksanaan, dalam tahap ini peneliti melakukan pretest kepada subjek dan menganalisa hasil jawaban. 3) tahap akhir, dalam tahap akhir peneliti menganalisis data, mendeskripsikan hasil penelitian dan menyusun laporan penelitian.

Instrumen utama adalah peneliti. Peneliti merupakan perencana, pelaksana pengumpulan data, analis, penafsir data, dan menjadi pelapor hasil penelitiannya. Instrumen pendukung pada penelitian ini berupa tes. Tes yang digunakan pada penelitian ini adalah tes kemampuan pemahaman matematis yang terdiri dari 5 soal berupa soal-soal dengan materi bangun datar . Pada masing-masing soal siswa diminta untuk menyelesaikan permasalahan yang diminta. Tes yang digunakan telah dikonsultasikan kepada pembimbing. Selain itu, rubrik penilaian tes disusun berdasarkan indikator pemahaman matematis yang telah ditentukan.

Berdasarkan rubrik tersebut peneliti dapat menentukan apakah siswa memenuhi masing-masing indikator pemahaman atau tidak. Data yang diperoleh kemudian disesuaikan dengan rubrik penilaian tes. Selanjutnya diolah dengan menentukan presentase keterpenuhan masing- masing indikator pemahaman matematis. Kemampuan pemahaman matematis siswa dikatakan tinggi apabila persentase keterpenuhan indikator pemahaman matematis minimal $75 \%$ siswa pada setiap soal.

\section{HASIL DAN PEMBAHASAN}

\section{Hasil}

Penelitian ini dilakukan kepada beberapa siswa kelas VII SMP dari salah satu sekolah yang berada di Karawang. Sampel yang diambil yaitu 5 orang siswa yang dipilih secara acak.

Tabel 1. Penskoran Pemahaman 


\begin{tabular}{clc}
\hline $\begin{array}{c}\text { Tingkat } \\
\text { Pemahaman }\end{array}$ & \multicolumn{1}{c}{ Kriteria } & skor \\
\hline Tidak Paham & $\begin{array}{l}\text { Jawaban hanya mengulang pertanyaan } \\
\text { Miskonsepsi }\end{array}$ & $\begin{array}{l}\text { Jawaban menunjukan salah paham yang berdasar } \\
\text { tentang konsep yang dipelajari }\end{array}$ \\
Miskonsepsi & $\begin{array}{l}\text { Jawaban memberikan sebagian informasi yang } \\
\text { benar tapi menunjukan adanya kesalahan konsep } \\
\text { Sebagian }\end{array}$ & 2 \\
Paham Sebagian menjelaskan & $\begin{array}{l}\text { Jawaban benar dan mengandung paling sedikit } \\
\text { konsep ilmiah serta tidak mengandung satu } \\
\text { kesalahan konsep }\end{array}$ & 3 \\
Paham Seluruhnya & $\begin{array}{l}\text { Jawaban benar dan mengandung seluruh konsep } \\
\text { ilmiah }\end{array}$ & 4 \\
\hline
\end{tabular}

Hasil dari penelitian ini menggunakan hasil penskoran berdasarkan hasil soal tes uraian yang di sajikan berupa data. Berikut adalah data dari hasil penelitian:

Tabel 2. Data Hasil Penelitian

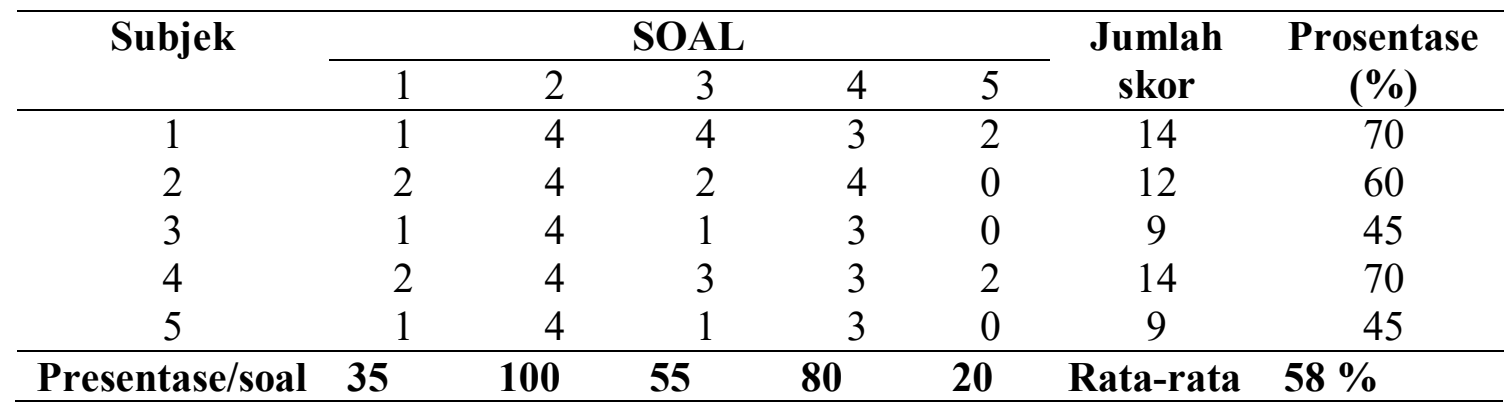

Dari data tersebut dapat diketahui ada beberapa soal yang tidak mencapai indikator. Berikut data soal yang tidak mencapai target indikator:

Tabel 3. Prosentase Pencapaian Indikator

\begin{tabular}{cccc}
\hline Indikator & $\begin{array}{c}\text { Mendefinisikan } \\
\text { konsep secara } \\
\text { verbal dan tulisan }\end{array}$ & $\begin{array}{c}\text { Mengidentifikasi } \\
\text { sifat-sifat suatu } \\
\text { konsep }\end{array}$ & $\begin{array}{c}\text { Menggunakan } \\
\text { model diagram dan } \\
\text { simbol-simbol } \\
\text { untuk }\end{array}$ \\
SMI & 4 & 4 & $\begin{array}{c}\text { mempresentasikan } \\
\text { suatu konsep }\end{array}$ \\
Rata-rata & 1.4 & 2.2 & 4 \\
presentase & $35 \%$ & $55 \%$ & 0.8 \\
\hline
\end{tabular}

Dari tabel dapat kita lihat bahwa kemampuan pemahaman matematis siswa masih kurang di setiap indikatornya. Indikator pertama merupakan mendefinisikan konsep secara verbal dari hasil analisis siswa kemampuan pemahaman siswa cukup. Indikator kedua merupakan mengidentifikasi sifat-sifat suatu konsep dari hasil analisi siswa kemampuan pemahaman sudah 
cukup. Indikator ketiga merupakan Menggunakan model diagram dan simbol-simbol untuk mempresentasikan suatu konsep dari hasil analisis siswa kemampuan pemahaman matematis siswa masih kurang.

\section{Pembahasan}

Hendriana \& Afrilianto, (2017) mangatakan penelitian merupakan proses mencari kebenaran dengan memenuhi langkah-langkah: adanya masalah, data dan referensi tentan masalah tersebut, dugaan sementara, menguji hipotesis, dan menarik kesimpulan. Dari tabel data hasil penelitian dapat dilihat bahwa rata-rata presentase kemampuan pemahaman matematis siswa dalam menyelesaikan soal yang diberikan oleh peneliti yang berjumlah 5 butir soal yaitu $58 \%$. Berdasarkan hasil tersebut, kemampuan pemahaman matematis yang dimiliki oleh siswa masih terbilang rendah. Berikut adalah pembahasan soal yang masih belum mencapai angka persentase yang diinginkan peneliti.

Pada soal no 1, siswa diminta untuk menjelaskan apakah setiap persegi panjang adalah jajargenjang. Dari hasil analisis ternyata hanya ad 2 siswa yang mendapat niali $2(40 \%)$ dan 3 siswa mendapat nilai $1(60 \%)$. Jawaban siswa seperti gambar berikut:

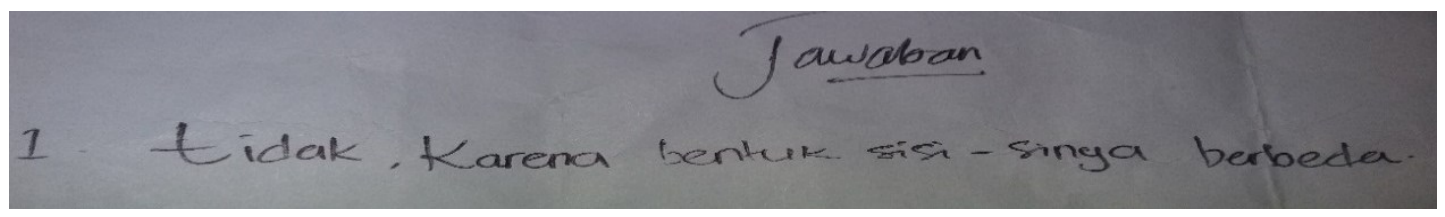

Gambar 1. Jawaban siswa soal no 1

Soal No 3

Perhatikan gambar berikut!

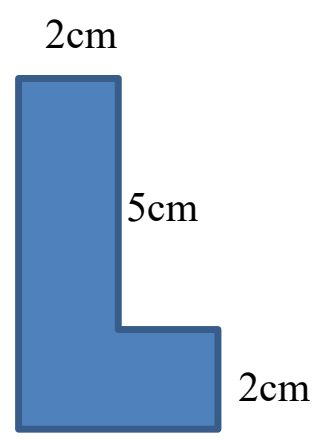

$2 \mathrm{~cm}$

Gambar 2. soal no 3

Hitunglah keliling dari gambar tersebut!

Pada soal no 3, siswa diminta untuk menghitung keliling bangun datar tersebut. Dari hasil analisis ada 1 siswa yang mendapat nilai 4 (20\%), 1 siswa mendapat nilai $3(20 \%)$, 1 siswa mendapat nilai $2(20 \%)$ dan 2 siswa mendapat nilai 1 (40\%). Jawaban siswa seperti gambar berikut: 


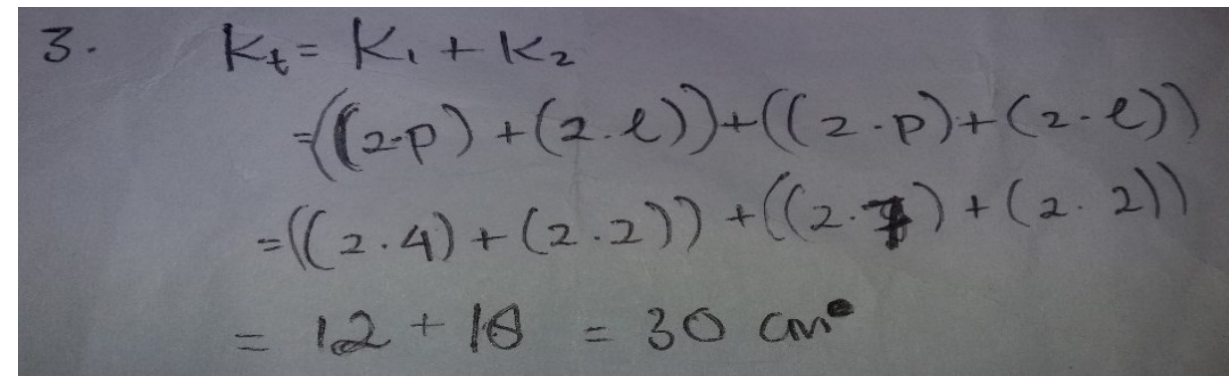

Gambar 3. Jawaban siswa soal no 3

\section{Soal No 5}

Jika luas layang-layang PQRS $=78,75 \mathrm{~cm}^{2}$

Tentukan panjang PQ!

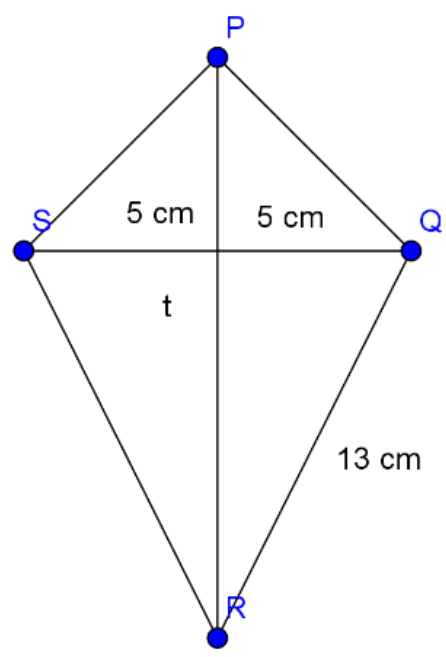

Gambar 4. soal no 5

Dan pada soal no 5, siswa di minta untuk menentukan panjang sisi dari suatu laying-layang. Dari hasil analisis ada 2 siswa yang mendapat nilai 2 (40\%) dan 3 siswa mendapat nilai $0(60 \%)$. Jawaban siswa hanya mengulang pertanyaan seperti gambar berikut:

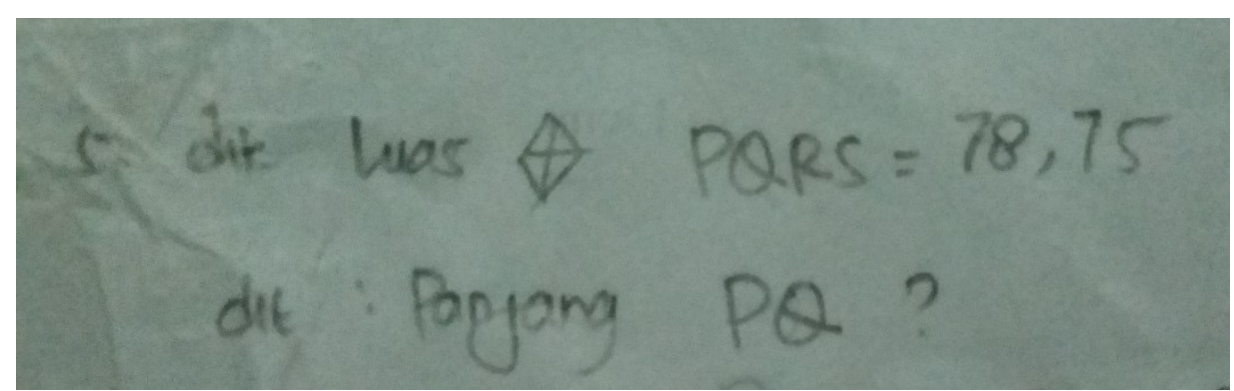

Gambar 5. Jawaban siswa soal no 5

Berdasarkan pembahasan diatas perlu diadakannya pembelajaran yang dapat meningkatkan minat belajar siswa. Tidak hanya dalam bentuk penugasan kepada siswa sependapat dengan yang dikatakan (Sumarmo, Hidayat, Zukarnaen, Hamidah, \& Sariningsih, 2012) Pembelajaran 
yang menugaskan siswa belajar sndiri secara terus menerus dalam waktu yang agak lama menimbulkan rasa bosan sehingga mengurangi kegairahan belajar siswa.

\section{KESIMPULAN}

Berdasarkan hasil analisis dan pembahasan, maka dapat disimpulkan kemampuan pemahaman matematis siswa kelas VIII dalam menyelesaikan soal bangun datar masih rendah. Hal tersebut ditunjukkan dengan hasil tes kemampuan pemahaman matematis siswa tidak maksimal. Siswa tidak dapat menerapkan konsep yang telah dipelajari sebelumnya dengan konsep yang terdapat pada bangun datar sehingga kesulitan dalam menyelesaikan soal. Siswa mengalami kesulitan dalam memahami soal karena siswa masih bingung dan belum mampu memaknai kalimat yang disajikan. Selain itu siswa lupa dengan materi bangun datar. Siswa juga kebingungan dalam memilih konsep yang harus digunakan dalam menyelesaikan soal. Meskipun siswa belum memperoleh jawaban yang tepat, tetapi siswa telah berusaha untuk menjawab soal dengan maksimal.

Hasil penelitian ini diharapkan dapat memberikan informasi kepada pihak sekolah mengenai kemampuan pmahaman matematis siswa. Mengingat pentingnya pemahaman matematis dan fakta mengenai kemampuan pemahaman matematis siswa, diharapkan guru mampu merancang kegiatan pembelajaran yang dapat memfasilitasi kemampuan pemahaman matematis siswa.

\section{DAFTAR PUSTAKA}

Afrilianto, M. (2012). Peningkatan Pemahaman Konsep dan Kompetensi Strategis Matematis Siswa SMP dengan Pendekatan Metaphorical Thinking. Infinity Journal, 1(2), 192-202.

Aripin, U. (2016). MENINGKATKAN KEMAMPUAN PEMAHAMAN MATEMATIK SISWA SMP MELALUI PENDEKATAN PEMBELAJARAN BERBASIS MASALAH. P2M STKIP Siliwangi, 2(1), 120-127.

Hendriana, H., \& Afrilianto, M. (2017). Langkah Praktis Penelitian Tindakan Kelas Bagi Guru. Bandung: Refika Aditama.

Hendriana, H., Rohaeti, E. E., \& Sumarmo, U. (2017). Hard Skills dan Soft Skills Matematik Siswa. Bandung: Refika Aditama.

Ruseffendi, E. T. (2005). Dasar-dasar penelitian pendidikan dan bidang non-eksakta lainnya. Bandung: Tarsito.

Sumarmo, U., Hidayat, W., Zukarnaen, R., Hamidah, M., \& Sariningsih, R. (2012). Kemampuan dan Disposisi Berpikir Logis, Kritis, dan Kreatif Matematik (Eksperimen terhadap Siswa SMA Menggunakan Pembelajaran Berbasis Masalah dan Strategi ThinkTalk-Write). Jurnal Pengajaran MIPA, 17(1), 17-33.

Tricahyo, D. (2016). Analisis kemampuan pemecahan masalah matematika berdasarkan langkah-langkah polya pada materi aritmatika sosial siswa kelas VII SMP N 1 Bringin. Jurnal Pendidikan Matematika FKIP-Universitas Kristen Satya Wacana Salatiga, 1, 1- 
20.

Ushalihah, A. (2017). MENINGKATKAN KEMAMPUAN PEMAHAMAN MATEMATIS MELALUI PENDEKATAN REALISTIC MATHEMATICS EDUCATION (Penelitian Eksperimen terhadap Siswa Kelas IV SDN Pasirbenteng II dan SDN Pasirbiru di Kecamatan Rancakalong, Kabupaten Sumedang). UNIVERSITAS PENDIDIKAN INDONESIA.

Warih, S., Dwi, P., Parta, I. N., \& Rahardjo, S. (2016). Analisis Kemampuan Koneksi Matematis Siswa Kelas VIII pada Materi Teorema Pythagoras. 